\title{
The Belt and Road Initiative and international relations theories: Challenges and a new research agenda
}

\author{
Hang Yuan \\ Sichuan University, \\ No. 24 South Section 1, Yihuan Road, Chengdu, China
}

For citation: Hang Yuan. The Belt and Road Initiative and international relations theories: Challenges and a new research agenda. Vestnik of Saint Petersburg University. International Relations, 2020, vol. 13, issue 1, pp. 33-46. https://doi.org/10.21638/spbu06.2020.103

\begin{abstract}
The majority of existing research on the Belt and Road Initiative (BRI) focuses primarily on its operation in past years. However, efforts to deepen an understanding of the BRI itself remain at an early stage. Some fundamental questions on its nature, scope, process and implications still remain and require clearer answers or even more debates. Scholars who fail to consider these larger questions risk developing their arguments on premature assumptions on the BRI and consequently overlooking very important elements of it. From the discipline of international relations (IR), this article aims to identify some key questions to the BRI and recommend a new research agenda. It argues that IR scholars face challenges to examine the BRI due to the BRI itself, as a puzzle, and limits of current dominant IR trends. This article suggests that a better understanding of the BRI involves a more open-minded conceptualization of it. The new research agenda on the BRI proposes to focus on five themes and related key questions and hypotheses. In order to tackle the complexity of the BRI, this agenda calls for more creative efforts, including a combination of various theoretical perspectives, and incorporation of more elements of non-western wisdom into analytical frameworks, including China and other countries. Being aware of the debates of incommensurability between paradigms and perspectives, this article suggests a pragmatic approach in acquiring knowledge on the BRI.
\end{abstract}

Keywords: Belt and Road Initiative, international relations, research agenda.

\section{Introduction}

In 2013 Chinese President XI Jinping proposed the Belt and Road Initiative (BRI) to the world. In past years, the BRI has attracted growing attention ranging from politicians to business elites, from China to its neighbors, from Asia to Europe and beyond. The BRI has become one buzzy word for observers, commentators and researchers in various academic disciplines including social sciences ${ }^{1}$, engineering and even natural science within and outside China ${ }^{2}[1-3]$. They have discussed the background and discourse of

${ }^{1}$ In July 2019, the author conducted search by retrieval of key words "Belt and Road" in the software of Endnote and found over 250 papers published during 2013-2019 in the Social Science Citation Index. The number of articles published each year are 10 in 2016, 32 in 2017, and about 100 in 2018 and 2019 respectively. Thus, the majority of these articles were published after 2018, which reflects great increase in academic attention to the BRI after 2018. Besides, the names of these authors indicate that the majority of these authors are ethnically Chinese or at least heavily influenced by Chinese culture.

${ }^{2}$ Leading international journals of science such as Nature and Science have published editorials and articles on the BRI. See recent texts, for instance, in references.

(C) Санкт-Петербургский государственный университет, 2020 
the BRI, followed by various reports issued by many think tanks and other institutions on its implements, progresses and challenges, as well as potential impact and implications for China and those countries involved [4]. The existing academic literature on the BRI focuses primarily on the operation and implications of this initiative in past years $[5 ; 6]$.

Yet the efforts to deepen understanding of it seemingly remain at an early stage. Some fundamental questions around the BRI - such as its nature, scope, process and implications for China and the whole world - still need richer answers or even more debates. For instance, we need to contemplate on such questions: from which perspectives and frameworks could we examine the BRI and what are the differences between outcomes of these perspectives. Scholars who fail to consider these deeper questions of the BRI would risk of developing their arguments on the basis of some premature assumptions of it and accordingly missing very important elements or even aspects of it. In fact, different scholars often tend to focus on different elements of it. While some Chinese stress the significance of the BRI in China's current external relations, international observers may ask what exactly China wants and how will China change the world. Arguably, the BRI remains a puzzle requiring for further research and debates, including advances in conceptualization.

To advance this line of discussion, this article aims to identify some key questions to the studies of the BRI from the discipline of international relations (IR). It argues that the puzzle of the BRI can be viewed as a case of the broader puzzle of China's approach to the world. Accordingly, to better examine the BRI means to better conceptualize and theorize China's approach to the world, namely, its philosophy and practice of foreign policy. That is, we can better explore and understand a specific puzzle of the BRI by linking it to the broader one: China's approach to the world. Using a metaphor, we can understand a tree in a forest mainly through two perspectives: focusing on the tree itself and locating it in the whole forest. This article suggests to combine the two perspectives to tackle the puzzle of the BRI and to advance broader research on China's approach to the world. This article submits a new research agenda. It is not to present detailed answers to all of those fundamental questions or to offer a standard and comprehensive template for all future studies. Instead, it attempts to present some hints to some interesting and promising lines of thoughts to enrich future research.

\section{The BRI as a puzzle}

The research themes of the BRI requires scholars to consider various dimensions of this initiative. Hypothetically, scholars can start from its background, main content, implementation and experience/lessons learned since 2013 to tackle more fundamental questions around the philosophical basis of Chinese foreign policy and divergent theoretical perspectives to frame it.

The existing academic literature in English has covered some dimensions. Scholars have discussed on the nature, scope, implications of the BRI for the local, national (such as related countries), regional (related regions and continents such as Asia, Europe and Africa) and global. The first perspective is to link the BRI to China's foreign policy [7], viewing it as China's geopolitical plan or grand strategy [8-11]. Some have discussed its implications for countries, regions, and seas [12-15], including Asia [16], Europe [17; $18]$ and Eurasia in general [19-21]. Issues of investment [22; 23], trade [24] and environment $[25 ; 26]$ received much attention. The second perspective is to link the BRI to topics 
at regional and international levels such as regionalism [27], international law [28], and international organizations such as the Asian Infrastructure Investment Bank (AIIB) [29; 30]. The third perspective is around global issues and global governance such as global finance [31;32], global development [33], and global health [34]. The fourth perspective is more around other actors' perceptions of the BRI [35], including Russia [36], and responses to China's narratives on it $[37 ; 38]$. All of the discussions from above perspectives are interesting, inspiring and helpful for focusing on some important aspects and details of the BRI to deepen our understanding of it.

Meanwhile, there are also prior or more fundamental questions to the BRI which require more examination, reflections and debates. There are basic questions: what is the BRI, why is the BRI and how the BRI is realized? Arguably, the BRI remains a puzzle not only for policy commentators but also for academics. For many the BRI is associated with paradoxes, with which not only international observers are prone to be confused, but also Chinese scholars themselves. For instance, Wang Yiwei, one of leading Chinese scholars on the BRI, has listed a number of paradoxes for China on the BRI [39]. Indeed, the BRI has brought challenges in terms of what, why and how questions for the IR scholars to understand, explain and interpret it. For instance, there are debates on the motivation of China in the BRI. Why was the BRI proposed in 2013 and why it is different from other initiative, plans, strategies [40]? Some have realized the necessity of advancing the efforts to conceptualize and theorize the themes of the BRI [41-44].

Arguably, the challenges which the BRI has brought about to the IR research result both from the BRI itself and current dominant IR thoughts on which many researchers rely to analyze the world. In this article, the BRI as a puzzle has three meanings.

Firstly, one main feature of the BRI is fuzziness, vagueness and blurring. Although China has issued a series of official documents of the $\mathrm{BRI}^{3}$, up to date there is no one standard official definition which provide explicit and rich answers to basic questions of it: who, where, when, how, why and which. Specifically, who are to be involved in this initiative? Where does the BRI cover in the world? How much is the budget which China will set for it? How is it going on? How long will it exist? What are its phases of life cycle, which supposedly can include the beginning, revising, climax and ending? And why is it successful or unsuccessful, according to which criteria?

Thus, it is possible that different observers have different interpretations of the BRI. For instance, many studies focus on the infrastructure projects. However, the BRI is not simply an infrastructure cooperation. Instead, China's documents on the BRI reveal that it is featured by multi-sectoral and multi-level cooperation in five fields, including policy coordination, connectivity of infrastructure, unimpeded trade, financial integration, and closer people-to-people ties. In Chinese language, they are called 五通 (five connectivity). Another example is that some view the BRI as simply China's unilateral strategy, plan or project. In fact, in proposing the BRI as an international initiative, China has explicitly pledged to uphold the principles of extensive consultation, joint contribution, and shared benefits. Hypothetically, at least, the BRI is not merely China's unilateral project.

Secondly, the above feature is closely related to the Chinese approach to proposing the BRI. Typically, Chinese officials firstly propose a new idea or concept which yet often has no explicit official definition to international audience, and then provide more details

\footnotetext{
${ }^{3}$ See those documents on the official website of the BRI: https://eng.yidaiyilu.gov.cn.
} 
of that idea later in response to the curiosity of the audience. That approach is in line with China's approach in domestic reforms and opening-up, which involves policy experiments in trail-and-error patterns, often starting with certain practice or idea followed by providing more details to interpret that practice or idea. Thus, although the BRI was proposed in 2013, more details appeared later in a variety of Chinese official documents $[45 ; 46]$. This approach also means changing and revision of details. That is, it is possible that connotation and denotation of the BRI are developing and expanding. For instance, regarding how many countries are to be under the BRI, at the beginning, it seems to be 65 countries according to some sources. Later some guess that that the number should be over 65. A recent research report from Peiking University included 94 countries in their analysis of the BRI [47]. Up to date, many people are still guessing without clear answers. Another consequence is that the scope of the BRI is extending from original versions. For instance, in the infrastructure field, someone has already discussed extending the connectivity from building roads, railways, bridges, ports, energy pipelines to cyber, digital level and outer space. Thus, the questions are where is the border of the BRI? Is the BRI equal to everything?

Although this approach of China can entail flexibility of the BRI which is brought by the vagueness, it sometimes also invites misunderstandings on the BRI. Since the BRI is the No. 1 project of China's current external policy, it is also very attractive for Chinese domestic actors, who are inclined to label their own activities/plans/projects as the part under the BRI to seek support from Chinese Central Government. Chinese officials will also have bright prospective in their promotion because of their achievement in the BRI. In fact, there once were rushes of labelling various projects with the BRI and Chinese Central Government had to curb that rush by urging that all local projects within the framework of the BRI should be authenticated and authorized by the Central Government.

Thirdly, the BRI depends on interactions between China and others. Since the BRI is not merely China's unilateral strategy or plan, it relies on the responses of other actors. China is not able to solely decide the future of the BRI. It is China and others that jointly shape the BRI. As China claimed that the BRI is "originated in China, but it belongs to the world", "focuses on Asia, Europe and Africa, but is open to all partners" [46]. The responses of others are various and changing. While some countries such as the United States of America (USA) is firmly opposed to it, it has received increasing support from many countries in Asia, Africa and Latin America. The attitudes and responses of other countries to the BRI are likely to change due to their changing domestic situation such as forming new governments and changing international landscape as well.

\section{Challenges to the IR}

The above three features of the BRI as a puzzle altogether require more conceptual, theoretical and even methodological discussions in the current IR discipline. However, the existing IR discipline, in which Western perspectives dominate research, is seemingly not sufficient for providing all satisfactory answers to the puzzle. Challenges or contradictions lie in at minimum four aspects.

The first is at the level of cultural difference between the West and China. The prevailing Western IR thoughts are basically based on experience in the West, mainly Europe and the USA, providing observations, statements and reflections of the world from the 
Western perspective. Typically, the Western IR literature often demands for distinction, concise and preciousness in using a concept such as power. Often the concepts are the beginning of logical reasoning in IR research. In contrast, as mentioned above, Chinese style of international cooperation is often characterized by fuzziness at the beginning as is reflected in the BRI. In fact, new ideas or concepts proposed by Chinese government are often lacking of explicit and detailed definitions at first and subject to subsequent more policy interpretations by Chinese scholars and/or think tanks [48; 49].

While lacking of clear definitions of the concepts such as the BRI enable China to adjust and revise some details of its proposals, this approach also leaves room for different understanding and debates on those proposals among international observers and researchers. Thus, while it is important to examine some aspects and details of the BRI, it is equal or even more important to ponder deeply over and clarify the nature and scope of the initiative. Otherwise, if scholars do not think about these and clarify the common ground among them on the basic questions to the BRI before their going to conduct studies around some details of the BRI, then their discussions and debates would not have common basis and very likely end up with more confusions.

The second is that the existing English IR literature does not sufficiently examine China through Chinese perspective. While there are many citations of Western popular terminology such as grand strategy to label the BRI, there is little literature mentioning Chinese authentic discourse such as "a regional community of common destiny". One possible reason for low citations of Chinese authentic discourse on the BRI and China's foreign policy in general is that international authors are not familiar with Chinese terminologies which are in Chinese language from Chinese governmental original discourse. Another reason is that Chinese discourse on the BRI emerged later than 2013 and has not received sufficient attention of international academics in the IR. Anyway, it is questionable in methodology to analyze China without sufficient considering Chinese perspective.

The third is on the BRI's unfolding process of interactions and policy experimentation. In the current IR research, scholars often pursue certainty through seeking to reduce uncertainty. Yet as explained above, the BRI remains largely uncertain because of its unfolding process shaped by various actors within and outside China. Since 2013 Chinese government has been waiting for and observing the response of others including states and non-state actors. In turn, those responses can have impact on China's ideas on the BRI. One country's responses on the BRI can also influence those of others. Thus, interactions among various actors within and outside China at local, national, regional and global levels can be very complex and full of uncertainty. This uncertainty naturally associated with complexity inevitably demands more dynamic and sophisticated analytical frameworks than current prevailing ones from realism, liberalism and constructivism in IR to better understand the BRI. This is not claim that the existing IR concepts and analytical frameworks are not useful, which might provide some valuable building blocks. Yet how to develop more powerful analytical frameworks on the basis of the existing ones to better understand and explain the complex processes of the BRI remains a challenging task.

Finally, at methodological level, there is a gap between current IR approaches (such as deduction and induction) and pragmaticism in practice of the BRI. The prevailing IR research often stresses deduction: a research starts with a perspective, concept or analytical framework followed by collecting and analyzing the empirical data. However, as the BRI itself remains as a puzzle so far, it is difficult to avoid starting with an assumed 
concept of the BRI, which is often premature and questionable in capturing the nature of it. For instance, scholars may simply assume the BRI as an infrastructure megaproject or grand strategy and then jump into some conclusions. Yet as discussed before, more careful examination of the BRI can easily reveal that the BRI is not equal to infrastructure or geopolitical plan of China, because the BRI is not China's unilateral plan. Instead, the $\mathrm{BRI}$ is more an international initiative which involves trail-and-error, learning by doing, and experiments. Thus, inductive research starting with observation and data collection without too early jumping into premature statements seems more helpful in analyzing the BRI. In addition, some IR scholars once suggested, pragmaticism is more suitable to analyze this kind of phenomenon such as trial-and-error processes [50-52]. Yet literature of pragmaticism remains little in the existing IR discipline.

\section{To conceptualize China's approach to the world: A new research agenda}

The BRI is one important initiative of China to the world. In a sense, the puzzle of the BRI is one case of puzzle of China's approach to the world. Better understanding of the BRI needs better understanding of China's approach to the world. We can only improve our research of the BRI through putting it in the broader and deeper research of China's approach to the world. This article argues that to examine the BRI is one stream of efforts to conceptualize and theorize China's approach to the world, including its the philosophy and practice of its foreign policy, and interactions with other players.

This article suggests that better understanding of the BRI involves more open-minded conceptualization of it in IR research. This conceptualization needs firstly to tackle two issues: what is the nature and scope of the BRI, and how to build more powerful analytical frameworks for the BRI. Accordingly, this article submits a new research agenda which calls for more attention to five themes of the BRI. The first theme concerns the nature and scope of the BRI. The other four themes concern how to frame the BRI in the world. In particular, it recommends to incorporate more elements of non-western wisdom, in particular Chinese philosophy and thoughts into analytical frameworks.

\section{Theme one: The nature and scope of the BRI}

This theme requires answers to two sets of fundamental questions to conceptualize the BRI. One set is about the nature of the BRI: what is the nature of the BRI, in terms of rationale, legitimacy and value? Which perspectives are appropriate to frame the BRI? Is it a strategy or initiative as its name demonstrates? The other set is about the scope: what is the scope of the BRI, in terms of spatial, temporal, financial, social and environmental dimensions? How is the BRI implemented? What are the implications?

To answer these questions, this article submits that the first step is to go back to the origins of the BRI, in particular the original official documents issued by Chinese government ${ }^{4}$. Carefully reading through those documents can help avoid biases due to some researchers' casual interpretation, hearsay, guesswork, or stereotypes of China's proposals on the BRI. Another step is to carefully distinguish between initiative and other concepts such as grand strategy, plan and project. As these concepts entail different meanings, those

${ }^{4}$ Those documents are available on the official website of the BRI, some of which are in several languages. 
subtle differences should be clarified and identified. Although academics perhaps disagree with each other on how to define these concepts and how to set up criteria to distinguish them, these different concepts are hypothetically not interchangeable.

Regarding the nature of the BRI, one promising hypothesis is to capture the complexity of it as an initiative which involves multi-sectoral, multi-level and multi-process phenomena. Instead of viewing it as a simple initiative in a narrow sector of economy such as infrastructure or trade, this hypothesis stresses the multi-sectoral initiative which involves various governmental and non-governmental actors at levels from local to global. The interactions among those actors at the same level and different levels are complex, which involve multi-process of discussions, negotiations, consensus building, and even disputes resolving. That is, the interactions are definitely not one-way process from China to other countries. In those multi-process, various policy transfer, norms transfer, policy learning, trail-and-error, rule setting and revision can occur. Putting these three dimensions - sector, level and processes - together, the picture of the BRI is indeed very complex. There are many more questions to be answered on the interrelations and interplays between different sectors, between different levels, and between different processes. For instance, how trade or investment ties can affect people-to-people exchanges between two countries joining the BRI? How does the development of ties between local entities in different countries contribute to the building of "a global community of shared future" which is expected by China?

Another hypothesis is to be aware of the changing scope of the BRI, which can lie in spatial, temporal, and issue areas. It is important to note that connotation and denotation of the BRI are developing and expanding. For instance, as China claimed that the BRI is open to the world, the spatial scope of the cooperation within the BRI is extending. Since 2013 the numbers of countries which are interested in joining it through signing memorandum of understandings (MOUs) or cooperation agreements with China are on the rise. Meanwhile, the issue areas of cooperation around the BRI have already expanded from the original 五通 (five connectivity) to more related fields such as scientific and technological innovation, education, health and medicine, ecological and environmental protection linked to the United Nations 2030 Agenda for Sustainable Development. In China's recent documents, the BRI is expected to become a road of peace, prosperity, opening up, green development, innovation, connected civilizations, and clean government [46]. In order to better capture the complexity and changing scope of the BRI, future research can consider more sophisticated analytical frameworks, research methods and technologies such as the big data tools ${ }^{5}[53 ; 54]$.

\section{Theme two: The BRI as the output in China's foreign relations}

Here the output means that the BRI itself can be viewed and examined as an initiative and discourse. Firstly, along the line of initiative, future studies could concentrate on the background, intention, objectives, principles, methods and means of the BRI as an important international initiative proposed by China. Discussions can be around questions such as why the BRI was proposed, why in 2013, what are the objectives, principles, methods and means of it? One direction is to link the BRI to China's approach to the world. This involves discussing the cultural background of the BRI, which reflects certain ways of

\footnotetext{
${ }^{5}$ There are already some studies on using big data to examine the BRI. See some, for example, in references.
} 
thinking in Chinese foreign policy, in the context of Chinese traditions and philosophical basis of foreign policy which can date back, through the decades after 1978 and years after 1949, to ancient China over 2000 years ago.

For instance, regarding the principles and methods, there can be discussion on the style of the BRI and China's international initiatives in general. Why was the BRI initiated without clear and more detailed definition and policy guidelines at the very beginning. One hypothesis is that this represents a Chinese style of foreign policy, which in turn is closely associated with domestic practice. In particular, one main experience in contemporary China is to conduct reforms through policy experiments, or more popular saying in Chinese:摸着石头过河 (crossing the river by feeling for stones), which "calls for prudence in feeling our way forward in unfamiliar territory, and testing the waters before a major course of action aiming at achieving breakthroughs is launched", and "encourages innovation, exploration, and trailblazing efforts, while at the same time emphasizing the importance of identifying and promoting best practices on the basis of lessons learned" [55]. Namely, it basically means trial-and-error.

Along this line of discussion, we can ask more questions. Is it possible to summarize China's approach to the world? Whether the BRI as a case represents a general style of Chinese approach to international initiatives as a mode: to firstly propose a rough idea and see what will happen and have more trail-and-error processes? To what extent does China follow this mode in proposing its own ideas or concepts to the world, such as "contributing Chinee wisdom (中国智慧)” and “Chinese contribution (中国贡献) to global governance"? It seems that up to date no one has explicitly defined what is Chinese wisdom or what are the specific content of it.

Secondly, along the line of discourse, the BRI is widely recognized as one important component of China's foreign policy and proposals on international relations. In past years, Chinese leaders have proposed a series of new concepts on international relations and world affairs, such as "major country diplomacy with Chinese characteristics（中国 特色大国外交)", and “building a global community of shared future (构建人类命运共 同体)". The BRI is viewed as an important platform for realizing the "global community of shared future" [46]. What are the relations between the BRI and other concepts on China's diplomacy proposed by current Chinese leadership? How to locate the ideas of the BRI to broader discourse on foreign policy dating back to earlier years of the People's Republic of China since 1949? Some comparison between the discourse of the BRI and that of China's other international initiatives in past decades can help reveal the changing patterns of discourse in China's foreign policy and related domestic policy on economic and social development.

\section{Theme three: The BRI as processes since 2013}

The BRI is not a one-shot initiative which can be immediately accomplished. Instead, it has existed since 2013, and will last as China's flagship international initiative in the foreseeable future. Thus, it makes sense to note the temporal dimension of this initiative which entails processes at several levels. Firstly, at unilateral level, there is a process of policy development originally from China. As discussed above, China initiated an idea firstly to its Asian partners, waited for the response of the audience, and gradually developed more details of the BRI. There are domestic processes within China, from desk works of 
drafting documents to setting up institutions at national level to promote and implement the details. Secondly, there are also international processes through various bilateral and multilateral mechanisms. At the bilateral level, China invited other countries and international organizations to cooperate on the BRI, through signing the MOUs and agreements and launching key concrete projects. At multilateral level, in order to reach consensus on the BRI, China offered invitations to all countries and international organizations in the world to have dialogues, including the Belt and Road Forums for International Cooperation held in Beijing in 2017 and 2019. Thirdly, the implementation of the BRI actually involves various actors at local, national, regional and global levels, who are involved in complex interactions within and trans various levels.

Hypothetically, the task to examine the BRI as processes involves two aspects of one thing: temporal (the life cycle of the BRI) and spatial (interactions within and cross levels). The study of the BRI's life cycle mainly addresses questions such as what are the stages of the BRI, how does it move from one stage to another, what are important factors influencing the life cycle. This line of study concerns stages such as planning, scheduling, joining, networking, implementation, problems emerging and resolving, plan adjustment, and projects finishing. The study of interactions asks questions such as what are the interactions involved within and cross levels, which types are they, why do they exist, whether and how do they interrelate and interact with each other. The research on interactions can concern consensus building (for example, through dialogues, persuasion and cooperation), rule setting ( for example, through negotiations, bargaining and coordination), opposing, competition, compromising, secession, disputes resolving, and international diffusion of norms, standards and best practices. There are some analytical frameworks in the IR to be used to discuss the processes of the BRI. For instance, from the perspective of rational choice institutionalism, some viewed the BRI as a 'geo-functional institutionalist' project, which is feasible for China to promote in a functionalist way in a world dominated by the west [56].

Another important subtopic is on various actors' perceptions of and attitudes to the BRI. In particular, it is important to examine how other states and peoples outside China perceive the BRI and what their responses are. While the BRI is embraced by some countries, it also faces obstacles and a "counter push" from other players to prevent China's rise and increasing influence in the world [57]. Why are some states more supportive on it than others? Whether and how do states and non-state actors change their perceptions on the BRI? Have they been disappointed or not up to date? What are important factors of the changes?

\section{Theme four: The BRI as an input to the world}

The impact and implications of the BRI can be examined at three circles: China itself, countries involved, and the world in general. This needs to be scrutinized further. Firstly, it is to be researched what the impact of the BRI on China itself is, including domestic economic, social and regional situation. To what extent is the BRI in line with China's domestic development and and external relations in general? Secondly, the impact of the BRI on other countries and regions involved such as Asia, Europe and Africa, is worth full discussing. To what extent does the BRI contribute to the development of, and the integration in, East Asia, Central Asia, Eurasia and broader regions? Thirdly, at global level, it is to 
examine the implications of the BRI for international relations, including geoeconomics, geopolitics, global governance, and international order. At all of these circles, it is to be asked what the impact and implications of the BRI are, whether they are negative or positive, what the criteria is to judge and how to judge.

There are possible hypotheses. One is to focus on the ideational aspect - the discourse dimension of the BRI, which provides a perspective/framework to reorganize various ties or connections within and outside China. For instance, domestic actors in China support enhancing ties including trade, investment and development elements with their foreign counterparts. Similarly, the BRI can also serve as a framework for other countries to identify connections and related opportunities through which to boost their own development. In this sense, the BRI can been seen as a strategic narrative of China to shape how others perceive the world ${ }^{6}$ [58]. Yet, it is to be studied to what extent it reshaped the discourse of others about China, Eurasia, and the whole world. How did that happen? To what extent do other states and non-state actors accept China's strategic narrative on the BRI?

Another hypothesis is to focus on the material aspect of the impact of the BRI as an international project. This involves the examination of three related issues: 1) the effect on specific issue areas such as connectivity, investment and environment in target local, national and regional contexts, 2) general effect of issue areas linked together on Asia, Europe, Africa and broader regions, 3) broader implications for international order and global governance. Regarding the impact on specific issue areas, there are already debates such as the so-called "debt trap" [59-62]. Future research can advance discussions on problems already emerged, potential problems and risks with it, as well as resolving mechanisms and solutions needed. It is also important to discuss the impact of the BRI on global governance in dealing with common challenges to humankind.

In particular, the BRI's implication for international order is one important topic. There are debates on the end of the existing order dominated by the West and a new order. One influential view is that a new order is likely a thin and two thick bounded orders one led by China and the other by the USA [63]. Another view believes that "a more likely alternative is a world with little order - a world of deeper disarray" [64, p. 30]. Future research should answer to what extent the BRI will influence this process. Anyway, the more objective research the better. The implications of the BRI should not be overestimated or underestimated.

\section{Theme five: The comparative research on the BRI}

Comparison can help generate more insights of the BRI through putting it to various contexts. One direction is to compare the progresses in each of five connectivity, to access in which issue areas the BRI is more successful. Another direction is to focus on one issue area such as connectivity to compare the BRI and plans proposed by others such as the strategy of the European Union (EU) for connecting Europe and Asia [65], to reveal the similarities and differences between them. To what extent do these plans represent different approaches or models in international connectivity? Researchers can also discuss

${ }^{6}$ Strategic narrative is defined as 'a means for political actors to construct a shared meaning of the past, present and future of international politics to shape the behaviour of domestic and international actors'. See [58]. 
the prospect of the synthesis or competition of these plans. From broader perspective of international relations, future research can also concern the difference between the BRI and other great initiatives and programs in the past and present such as the Marshall Plan, also known as the European Recovery Program, proposed by the USA after the World War Two. Why, and how, are they different? There are already some articles on such comparison [66]. Yet further discussions can go to more fundamental layers such as the philosophical basis of foreign policy of China, the USA, the EU, Germany after 1945, Japan, India, and so on.

\section{Research challenges ahead}

The above five themes of the BRI require deeper research on it, which in turn requires theoretical and methodological innovations to tackle challenges ahead. At theoretical level, challenges are around at minimum on two debates. The first is about theoretical monism and pluralism. Often IR scholars tend to adopt a single theoretical perspective and conduct a deep analysis on certain aspects of the phenomenon of interest. In contrast to this theoretical monism, authors endorsing pluralism suggest to combine different perspectives and paradigms to concern the whole story. This division reflects the deeper division between reductionism and holism at methodological level. Some IR scholars have suggested that researcher need to move from "paradigm wars" to "analytical eclecticism" [67]. For better understanding of the BRI which is very complex, this article suggests to pay more attention to theoretical pluralism, which leaves more room for efforts to trying various combinations of theoretical perspectives and paradigms.

The second is about incorporating more elements of non-western wisdom, including that of China and other countries alongside the BRI. The world is so diverse. It is obviously that not every non-western country follows western way of thinking. As the BRI is joined by many non-western countries, it is important to analyze the international relations in these regions in their own cultures and perspectives. That is to study and understand nonwestern nations in non-western ways. For instance, many original ideas and concepts from Chinese official discourse on the BRI deserve more academic attention such as principles of building the BRI which were mentioned in official documents on the BRI, as well as the patterns, mode and styles of China's practice in pushing forward the BRI. The philosophy and practice of China's foreign policy are worth better theorizing by focusing on the cases of the BRI. Some questions require richer answers. For instance, what is the relationship between the BRI and "the new type of international relations", and "building a community with a shared future for humankind", which are two key concepts China proposed to the world. Besides, comparative research is also needed to identify the common ground and differences between Chinese philosophy and practice of foreign policy and those of other countries. Similarly, the cultural and philosophical ideas of foreign policy of Russia, India and other countries should also be incorporated into the analytical frameworks.

Nevertheless, some scholars would raise the questions of incommensurability between paradigms. This is related to lasting debates at methodological level. Besides conventional approaches in the IR theorizing such as induction and deduction, some scholars argue that pragmaticism is also needed [51]. Here pragmaticism stresses abduction: the process of generating and choosing models, hypotheses and data analyzed in response to surprising findings. To avoid epistemological deadlock of mistakenly seeking "warranted 
knowledge through traditional scientific methods", a pragmatic approach is promising in combining knowledge generation and leaving more room for innovation [68]. It is true that these above debates at theoretical and methodological levels remain going on. Nevertheless, there is arguably never such warranted knowledge in the IR which is absolute correct without any more debates or tests. Thus, we cannot simply wait for the end of all theoretical and methodological debates to be sure that our coming knowledge production can be based on the conclusions of those debates which are unquestionable anymore. To advance the research on the BRI, we should at least be open-minded to explore various opportunities of accumulating knowledge which yet certainly to be repeatedly verified in the future.

\section{References}

1. Build a Sustainable Belt and Road, Editorial (2019), Nature, no. 569 (5), doi:10.1038/d41586-01901309-0, available at: https://www.nature.com/articles/d41586-019-01309-0 (accessed: 11.03.2019).

2. Masood, E. (2019), How China Is Redrawing the Map of World Science, Nature, no. 574, is. 7778, available at: https://www.nature.com/immersive/d41586-019-01124-7/index.html (accessed: 26.10.2019).

3. Ascensão, F., Fahrig, L., Clevenger, A., Corlett, R., Jaeger, J., Laurance, W. and Pereira, H. (2018), Environmental Challenges for the Belt and Road Initiative. Nature Sustainability, no. 1 (5), pp. 206-209.

4. ESCAP. China’s “One belt, One road” Initiative: An ESCAP Report (2017), Population \& Development Review, no. 43 (3), pp. 583-587.

5. Tekdal, V. (2018), China's Belt and Road Initiative: At the Crossroads of Challenges and Ambitions, The Pacific Review, no. 31 (3), pp. 373-390.

6. Zhai, F. (2018), China's Belt and Road Initiative: A Preliminary Quantitative Assessment, Journal of Asian Economics, no. 55, pp. 84-92.

7. Ferdinand, P. (2016), Westward ho - the China Dream and 'One Belt, One Road': Chinese Foreign Policy under Xi Jinping, International Affairs, no. 92 (4), pp. 941-957.

8. Blanchard, F., Colin, F. (2017), The Geopolitics of China's Maritime Silk Road Initiative, Geopolitics, no. 22 (2), pp. 223-245.

9. Clarke, M. (2017), The Belt and Road Initiative: China's New Grand Strategy? Asia Policy, no. 24 (1), pp. 71-79.

10. Wang, Y. (2016), Offensive for Defensive: the Belt and Road Initiative and China's New Grand Strategy, The Pacific Review, no. 29 (3), pp. 455-463.

11. Andornino, B. (2017), The Belt and Road Initiative in China's Emerging Grand Strategy of Connective Leadership, China \& World Economy, no. 25 (5), pp. 4-22.

12. Kamel, S. (2018), China's Belt and Road Initiative: Implications for the Middle East, Cambridge Review of International Affairs, no. 31 (1), pp. 76-95.

13. Clarke, M. (2016), 'One Belt, One Road' and China’s Emerging Afghanistan Dilemma, Australian Journal of International Affairs, no. 70 (5), pp. 563-579.

14. Schinas, O. and Westarp, A., Graf von (2017), Assessing the Impact of the Maritime Silk Road, Journal of Ocean Engineering and Science, no. 2 (3), pp. 186-195.

15. Lee, P. et al. (2018), Research trends and agenda on the Belt and Road (B\&R) initiative with a focus on maritime transport, Maritime Policy \& Management, no. 45 (3), pp. 282-300.

16. Ma, J., et al. (2017), One Belt One Road (OBOR) Initiative in Central Asia: The Study of OBOR on China and Central Asia Agricultural Trade, Transformations in Business \& Economics, no. 16 (3), pp. 41-55.

17. Fardella, E. and Giorgio, P. (2017), The Belt and Road Initiative Impact on Europe: An Italian Perspective, China \& World Economy, no. 25 (5), pp. 125-138.

18. Vangeli, A. (2017), China's Engagement with the Sixteen Countries of Central, East and Southeast Europe under the Belt and Road Initiative, China \& World Economy, no. 25 (5), pp. 101-124.

19. Rolland, N. (2017), China's Eurasian Century? Political and Strategic Implications of the Belt and Road Initiative, National Bureau of Asian Research, Project MUSE, available at: muse.jhu.edu/book/52595 (accessed: 26.10.2019).

20. Kaczmarski, M. (2017), Two Ways of Influence-Building: The Eurasian Economic Union and the One Belt, One Road Initiative, Europe-Asia Studies, no. 69 (7), pp. 1027-1046. 
21. Mayer, M. (2018), China’s Rise as Eurasian Power: The Revival of the Silk Road and Its Consequences, Rethinking the Silk Road, ed. by Mayer, M., Palgrave Macmillan, Singapore, pp. 1-42.

22. Huang, J. (2016), Silk Road Economic Belt: Can Old BITs Fulfil China’s New Initiative? Journal of World Trade, no. 50 (4), pp. 733-754.

23. Huang, Y., Thomas, F. and He, X. (2017), The Stakeholder Analysis for SEA of Chinese Foreign Direct Investment: The Case of 'One Belt, One Road' Initiative in Pakistan, Impact Assessment and Project Appraisal, no. 35 (2), pp. 158-171.

24. Herrero, G., Xu, J. (2017), China's Belt and Road Initiative: Can Europe Expect Trade Gains? China \& World Economy, no. 25 (6), pp. 84-99.

25. Zhang, N., et al. (2017), Carbon Footprint of China's Belt and Road, Science, no. 357 (6356), pp. 1107-1107.

26. Tracy, F., et al. (2017), China's New Eurasian Ambitions: The Environmental Risks of the Silk Road Economic Belt, Eurasian Geography and Economics, no. 58 (1), pp. 56-88.

27. Kaczmarski, M. (2017), Non-western Visions of Regionalism: China's New Silk Road and Russia’s Eurasian Economic Union, International Affairs, no. 93 (6), pp. 1357-1376.

28. Wang, G. (2017), The Belt and Road Initiative in Quest for a Dispute Resolution Mechanism, Asia Pacific Law Review, no. 25 (1), pp. 1-16.

29. Gabusi, G. (2017), "Crossing the River by Feeling the Gold": The Asian Infrastructure Investment Bank and the Financial Support to the Belt and Road Initiative, China \& World Economy, no. 25 (5), pp. 2345.

30. Sanders, J. (2017), The Asian Infrastructure Investment Bank and the Belt and Road Initiative: Complementarities and Contrasts, Chinese Journal of International Law, no. 16 (2), pp. 367-371.

31. Tsui, Sit, et al. (2017), One Belt, One Road: China's Strategy for a New Global Financial Order, Monthly Review, no. 68 (8), pp. 36-45.

32. Zhang, F., et al. (2017), The Effect of RMB Internationalization on Belt and Road Initiative: Evidence from Bilateral Swap Agreements, Emerging Markets Finance and Trade, no. 53 (12), pp. 2845-2857.

33. Sarker, I., et al. (2018), One Belt One Road Initiative of China: Implication for Future of Global Development, Modern Economy, no. 9 (04), pp. 623-638.

34. Hu, R., Liu, R., Hu, N. (2017), China's Belt and Road Initiative from a Global Health Perspective, The Lancet Global Health, no. 5 (8), pp. e752-e753, DOI: 10.1016/S2214-109X(17)30250-4

35. Jacob, T. (2017), China's Belt and Road Initiative: Perspectives from India, China \& World Economy, no. 25 (5), pp. $78-100$.

36. Timofeev, I., Lissovolik, Y. and Filippova, L. (2017), Russia's Vision of the Belt and Road Initiative: From the Rivalry of the Great Powers to Forging a New Cooperation Model in Eurasia, China \& World Economy, no. 25 (5), pp. 62-77.

37. Sidaway, D. and Chih, W. (2017), Chinese Narratives on “One Belt, One Road” (一带一路) in Geopolitical and Imperial Contexts, The Professional Geographer, no. 69 (4), pp. 591-603.

38. Zeng, J. (2017), Does Europe Matter? The Role of Europe in Chinese Narratives of "One Belt One Road" and "New Type of Great Power Relations", JCMS: Journal of Common Market Studies, no. 55 (5), pp. 1162-1176.

39. Wang, Y. (2018), China's Dilemma on the Belt and Road Initiative, Gonggong waijiao jikan, no. 02, pp. $50-56+135$.

40. Yu, H. (2017), Motivation behind China's “One Belt, One Road” Initiatives and Establishment of the Asian Infrastructure Investment Bank, Journal of Contemporary China, no. 26 (105), pp. 353-368.

41. Cheng, K. (2016), Three Questions on China’s "Belt and Road Initiative", China Economic Review, no. 40 , pp. 309-313.

42. Huang, Y. (2016), Understanding China's Belt \& Road Initiative: Motivation, Framework and Assessment, China Economic Review, no. 40, pp. 314-321.

43. Lingliang, Z. (2016), Conceptual Analysis of China's Belt and Road Initiative: A Road towards a Regional Community of Common Destiny, Chinese Journal of International Law, no. 15 (3), pp. 517-541.

44. Rolland, N. (2017), China's "Belt and Road Initiative": Underwhelming or Game-changer? The Washington Quarterly, no. 40 (1), pp. 127-142.

45. Building the Belt and Road: Concept, Practice and China's Contribution (2017), The Office of the Leading Group for Promoting the Belt and Road Initiative, May 10, available at: https://eng.yidaiyilu.gov.cn/ zchj/qwfb/12731.htm (accessed: 23.10.2019).

46. The Belt and Road Initiative Progress, Contributions and Prospects Office of the Leading Group for Promoting the Belt and Road Initiative (2019), The Office of the Leading Group for Promoting the Belt 
and Road Initiative, April 22, available at: https://eng.yidaiyilu.gov.cn/zchj/qwfb/86739.htm (accessed: 23.10.2019).

47. World Premier of The Belt and Road Initiative: 2018 Report on Five Connectivity Indexes at Taihe Civilizations Forum, September 15, 2018, Institute of Ocean Research, Peking University, available at: https:// ocean.pku.edu.cn/info/1165/3077.htm (accessed: 21.09.2019).

48. Zeng, J. (2016), Constructing a "New Type of Great Power Relations": The State of Debate in China (1998-2014), British Journal of Politics \& International Relations, no. 18 (2), pp. 422-442.

49. Zeng, J., Xiao, Y. and Breslin, S. (2015), Securing China's Core Interests: The State of the Debate in China, International Affairs, no. 91 (2), pp. 245-266.

50. Friedrichs, J. and Kratochwil, F. (2009), On Acting and Knowing: How Pragmatism Can Advance International Relations Research and Methodology, International Organization, no. 63 (4), pp. 701-731, DOI: 10.1017/S0020818309990142.

51. Bauer, H. and Brighi, E. (2009), Introducing Pragmatism to International Relations, Pragmatism in International Relations, eds Bauer, H. and Brighi, E., Routledge, pp. 17-24.

52. Frankel Pratt, S. (2016), Pragmatism as Ontology, Not (Just) Epistemology: Exploring the Full Horizon of Pragmatism as an Approach to IR Theory, International Studies Review, no. 18 (3), pp. 508-527.

53. Guo, H., et al. (2017), DBAR: International Science Program for Sustainable Development of the Belt and Road Region Using Big Earth Data, Bulletin of Chinese Academy of Sciences, no. 32 (Z1), pp. 2-9.

54. García-Herrero, A., Xu, J. (2019), Countries' Perceptions of China’s Belt and Road Initiative: A Big Data Analysis, Bruegel Working Papers, Brussels, Febryary 6, available at: https://search.proquest.com/ope nview/90c63053dee380ee823f6cde71fc6383/1?pq-origsite=gscholar\&cbl=2043318 (accessed: 23.09.2019).

55. On Translation to English in China Keywords (2018), China Daily, March 1, available at: language. chinadaily.com.cn/a/201803/01/WS5b2cd425a3103349141de4df.html (accessed: 05.08.2019). (In Chinese)

56. Kaplan, Y. (2017), China's OBOR as a Geo-functional Institutionalist Project, Baltic Journal of European Studies, no. 7 (1), pp. 7-23.

57. Joshua, J. (2019), The Belt and Road Initiative and International Relations, The Belt and Road Initiative and the Global Economy, ed. by Joshua, J., Palgrave Macmillan, Cham, pp. 163-187.

58. Miskimmon, A., O'Loughlin, B. and Roselle, L. (2015), Strategic Narratives: A Response, Critical Studies on Security, no. 3 (3), pp. 341-344.

59. Chellaney, B. (2017), China’s Debt-trap Diplomacy, Project Syndicate, available at: https:// www.project-syndicate.org/commentary/china-one-belt-one-road-loans-debt-by-brahma-chellaney2017-01 ?barrier=accesspaylog (accessed: 22.05.2019).

60. Chellaney, B. (2017), Sri Lanka the Latest Victim of China's Debt-trap Diplomacy, Asia Times, available at: https://asiatimes.com/2017/12/sri-lanka-latest-victim-chinas-debt-trap-diplomacy/ (accessed: 22.05.2019).

61. Hodge, A. (2018), China’s Debt-trap Diplomacy Snares Our Asian Neighbours, The Weekend Australian, January 13.

62. Eszterhai, V. et al. (2019), China’s "Debt Trap Diplomacy”, in Africa: False Accusation or Reality? April 8, available at: http://www.geopolitika.hu/en/2019/04/08/chinas-debt-trap-diplomacy-in-africa-falseaccusation-or-reality/ (accessed: 03.08.2019).

63. Mearsheimer, J. (2019), Bound to Fail: The Rise and Fall of the Liberal International Order, International Security, no. 43 (4), pp. 7-50.

64. Haass, R. (2019), How a World Order Ends: And What Comes in Its Wake, Foreign Affairs, no. 98 (1), pp. 22-30.

65. EU Steps Up Its Strategy for Connecting Europe and Asia, Brussels, 19 September 2018, European Commission, available at: https://europa.eu/rapid/press-release_IP-18-5803_en.htm (accessed: 22.05.2019).

66. Shen, S. and Chan, W. (2018), A Comparative Study of the Belt and Road Initiative and the Marshall plan, Palgrave Communications, no. 4 (1), p. 32, DOI: 10.1057/s41599-018-0077-9.

67. Sil, R. and Katzenstein, P. (2010), Beyond Paradigms: Analytic Eclecticism in the Study of World Politics, Macmillan International Higher Education.

68. Friedrichs, J. and Kratochwil, F. (2009), On Acting and Knowing: How Pragmatism Can Advance International Relations Research and Methodology, International Organization, no. 63 (4), pp. 701-731.

Received: November 20, 2019 Accepted: December 16, 2019

Author's information:

Hang Yuan — PhD, Associate Professor; yuanhang@scu.edu.cn 